\title{
Expanding Department Visibility by Starting an Industry Council
}

\author{
Denise T. Ogden \\ Penn State University- Lehigh Valley \\ Gaetan T. Giannini \\ DeSales University \\ James R. Ogden \\ Kutztown University (Ret.)
}

Today's managers seek employees with strong communication skills who can apply knowledge in a business setting, while academic business departments seek exposure in their communities. Industry councils can be an effective tool for bridging this gap. As the business world adapts to technological change, education based on information will cede to education based on the generation of ideas. The creation of an industry council creates a repository of relevant knowledge combined with a cadre of seasoned professionals to foster an environment that frames the challenges of an industry in a manner that is useful to professional and instructive to students. Accordingly, council led competitions aid students in identifying problems and synthesizing information from multiple sources into solutions that simulate real business situations. This document outlines steps to start an industry council. While every experience will be different, this paper offers guidelines to help form a council. The authors share their experience and suggest a process to lessen the learning curve for others who may benefit from establishing an industry council.

Keywords: industry council, business-university partnership, experiential learning, professional association, co-curricular activities, case competitions, career development

\section{EXPANDING DEPARTMENT VISIBILITY BY STARTING AN INDUSTRY COUNCIL}

Changes in the education and business environments have prompted a demand for student-centered approaches to teaching (Lamont and Friedman 1997). Today's business managers seek employees with strong communication skills who can apply knowledge in a business setting. At the same time, academic business departments seek visibility in their communities and greater exposure at the state, national and international levels. Industry councils provide experiential learning for students and increased visibility for business departments. This document outlines steps to start an industry council. While every experience will be different, depending on policies and processes at the campus level, this paper offers a set of guidelines to help form a council. The authors share their experience with starting and managing an industry council. The suggested process is presented to help lessen the learning curve for others who may benefit from creating such an organization. 


\section{BACKGROUND}

There are many associations (aka business councils, industry councils, professional associations, professional councils) that center around a purpose or an industry. Whatever the name, these groups consist of people in a given profession that develop goals that advance the industry's presence in a defined community (local, state, national, international).

As the business world evolves and technological connectivity expands, education based on information will cede to education based on the generation of ideas. Creating an industry council creates a repository of relevant knowledge combined with a cadre of seasoned professionals to foster an environment conducive to framing the stressors and opportunities in an industry in a manner that is useful to its professional membership and instructive to students. Within this space, council-led competitions aid students in identifying problems and synthesizing information from an array of sources into solutions of sometimes ambiguous problems that simulate real business situations. The following are benefits to starting an industry council:

For the University

- Enhanced reputation and visibility

- Engage alumni, students, and community members

- Increased fundraising

- Hosting events that engage stakeholders

- Press coverage

- Bringing different academic departments together

- Networking with different organizations

- Potential scholarship development

- Exposure of the campus to the external community

- Sources for student internships

- Establishing the university as an authority in a given field.

- Input for curriculum design from professional council members.

For Members

- Networking

- Relationship building

- Knowledge sharing

- Gain influence

- Learn skills

- Enhance professional reputation

- Finding or becoming a mentor

- Become an industry advocate

- Attend events

- Engage with students

- Provides members, who are often alumni, an opportunity to stay involved in the university and give back to the community

Benefits for Businesses/Organizations

- Increased publicity/media coverage

- Access to student talent for internships/job candidates

- Case Competition sponsorship opportunities

- Networking opportunities with industry professionals, students, university faculty

- Opportunities to identify solutions to challenges through industry partnerships

\section{Formation Stages}

There are three stages in the formation of an industry council: 
- $\quad$ Stage 1 - Pre-Formation

- $\quad$ Stage 2 - Formation

- $\quad$ Stage 3 - Established Operations

\section{Stage 1 - Pre-Formation}

The pre-formation stage is a research activity. The goal is to determine the feasibility of an industry council and people of influence within an industry. Often a faculty or staff members may have significant experience within an industry. These experts are essential sources of information and potential champions for the endeavor. At this stage you will want to research industry trends in your area to determine:

- What industry councils/associations already exist?

- The unmet need(s) in the community that an industry council may fill.

- Expertise needed to support the industry and its community.

- Interested people who may be willing and able to support the council.

For example, research may uncover a large number of companies concentrated in a particular industry in your area. If there are no industry associations in the region to fill this group's informational, social, or professional needs an opportunity may exist. Ideally, there will be one or more faculty members at the institution that have expertise and contacts in this industry who are willing to act as a champion and bridge the gap between students and professional members. Without a campus stakeholder who is knowledgeable about the industry it will be challenging to launch an industry council. However, if the need is strong enough and there are funds available, a person may be hired to launch the industry association.

During the pre-formation stage, there may be several industries that emerge as viable candidates. Choose one area of focus to start. Criteria to determine which industry to pursue may be related to the following:

- Size of the industry

- Number of people who have expressed interest

- Available funding (grants, donations)

- A champion or champions who want to take the lead in the formation of the council

- Campus support of the endeavor

- Student interest

Preliminary Meetings. Once the research is completed, gather a group of university decision-makers to discuss and determine which industry to pursue. Recruit a person (preferably a faculty or staff member with experience in the industry) to champion the formation.

Convene a group of representatives from the industry to discuss the council's formation to gather ideas and get buy-in. While not required, it helps to have industry professionals that are Vice President level and higher involved in these discussions as they have the power to move initiatives forward. At this stage, discussions are informal. Ideas should be recorded as well as interest level and potential resources. There may be several smaller meetings and even one-on-one meetings to gather information and determine interest.

Benchmark Other Industry Groups. There are usually other organizations within your chosen industry that are active on a national or regional level. For example, when researching the formation of the Council for Retail and Sales (https://thecrs.org) the authors looked at the following established organizations:

- National Retail Federation

- David F. Miller Retail Center (University of Florida)

- Kohl's Center for Retailing (University of Wisconsin-Madison)

- Center of Retail Management (University of Houston Downtown)

- Retail Supply Chain Institute (Babson College)

- Retail Management Institute (Santa Clara University)

- Retail Leaders Industry Association 
By finding other similar organizations, one can learn about the structure, events, ties to the community and university, and how they are funded. Valuable information can be garnered from established organizations to help form your industry council.

Focus Groups. A focus group is a formalized method to gather information from a group of people. By inviting a group of people interested in forming an industry council, information can be gathered, which helps to frame the organization of the council and develop a formal proposal to be presented to the university and potential industry sponsors. A moderator is used to ask questions while an assistant records responses.

In our case, we invited small industry groups ( $5-8$ people) to gather information on the viability and potential activities of an industry council. Questions were decided upon in advance to help focus the discussion. Open-ended questions work best. Some questions to consider include:

- What are the benefits of starting an industry council?

- What obstacles might there be in starting an industry council?

- How could we get people involved in the council?

- What motivated people's decision to get involved in a council?

- How might students benefit from an industry council?

- How many high-level executives do we have access to in the industry that we can enlist for board members?

The focus groups helped to develop our mission and messaging. We also recruited focus group attendees to become involved in the council.

Surveys. Another method to collect information before the formation of an industry council is to conduct a survey. The survey should be sent to professionals in the industry, students and faculty, and staff. Surveys can be complicated, so recruiting a person who is well-versed in creating and deploying surveys is recommended. There are several advantages to surveying, including:

- They provide feedback from a large number of people

- Information collected can serve as a benchmark for future surveys

- Information collected can help determine need and seek support

- Information is collected that is not available from other sources

- Use in developing a proposal

Once an industry has been chosen, a proposal should be developed. This proposal is important because the people who make decisions (i.e., management, industry professionals, grant organizations) will read it and, based on the content, will decide whether to help form and grow the council. Items to include in the proposal include but are not limited to:

- Overview

- Rationale (Statement of Need)

- Goals

- Benefits

- Potential Programs

- Potential Partners

- Budget

- Resources Needed

- Sustainability (How will the council continue to exist once formed)

\section{Stage 2 - Formation}

Based on the ideas gathered in the pre-formation stage, draft a mission statement and an organizational plan. The plan helps to formulate the structure and goals for the organization. This stage can take a few months to a year, depending on how quickly your campus adopts the concept and provides resources to move forward. Be patient and make attempts to keep the ideas going.

Developing the Mission Statement. A mission statement expresses the purpose of your organization succinctly. It is challenging to develop because much will need to be expressed in a few words. This 
statement will become both a guide for your organization and a way to educate various stakeholders on your reason(s) for existence. Do not take this step lightly, as this information should appear on all your materials and will often be the first exposure to your organization for potential members. Nonprofithub.org provides an excellent document with steps to crafting a mission statement.

The Board of Directors. Once key decision-makers have approved the organizational plan, it is time to recruit a board of directors or advisory board. When choosing the board members, focus on individuals with skills and resources in different areas. Board members should be leaders in the industry and have a desire to get involved. Also, recruit university staff or faculty with interest in the area to be part of the board.

The first activities of the board should include:

- Approve/revise the mission statement

- Develop bylaws

- Form committees (such as membership, marketing, events, fundraising)

- Decide upon goals for the year

Develop Bylaws. Bylaws are written rules that help the organization function. Putting these rules on paper help to define how the organization will operate, the role of officers and committees, requirements for membership, and how and when meetings will be held.

Steps in developing bylaws include (Community Tool Box 2019)

- Gather examples from similar organizations

- Decide who will write the bylaws and the approval process

- Write the first draft

- Meet as a group to discuss the proposed bylaws

- Complete and approve the final draft

Once bylaws are completed, it is crucial to abide by the rules and periodically review the bylaws to incorporate changes in the organization's structure.

Infrastructure. The formation of infrastructure is based on the organizational plan. Aspects of infrastructure include:

- Determining location, contact information

- Developing a website and social media presence

- Developing processes for buying materials, paying bills, collecting dues, and other monies

- Determining if an executive director will be hired on a full-time or part-time basis (depends on funding) or if the organization will be entirely run by the volunteer board

- Developing promotional material

Each university has policies and processes in place; the challenge is to adapt to existing procedures. This is often difficult as an industry group makes decisions and acts more quickly than existing university processes may allow. There is bound to be frustration during the first year, but this will lessen as the council leaders learn the ins and outs of policies and procedures.

Financing Operations. If possible, obtain sponsorships during the formation stage. This can be time intensive as face-to-face meetings with potential donors and sponsors are the most effective. Use networks and colleagues to generate potential companies and people with a stake in the council's mission and ongoing success.

There are several sources to finance the operations of an industry council, including grants, dues, events, sponsorships, and training. Many companies have community grants that are an excellent source of funding.

One of the first decisions of the board is whether or not you will charge dues, and if so, how much will members be charged yearly. If you decide to charge dues, make sure the benefits provided meet or exceed the cost of dues. Members often think about the cost and benefit of membership, so it is essential to obtain feedback from members to gauge satisfaction levels. In our case, member dues were forgone initially in order to build critical mass of members. 
According to Association Advisor (2017), sources of non-dues revenue include conferences and events (41\%), corporate partnerships/affinity programs (24\%), continuing education/training (24\%), and donations $(12 \%)$.

FIGURE 1

INDUSTRY COUNCIL NON-DUES REVENUE SOURCES

What are your most valuable
sources of non-dues revenue?
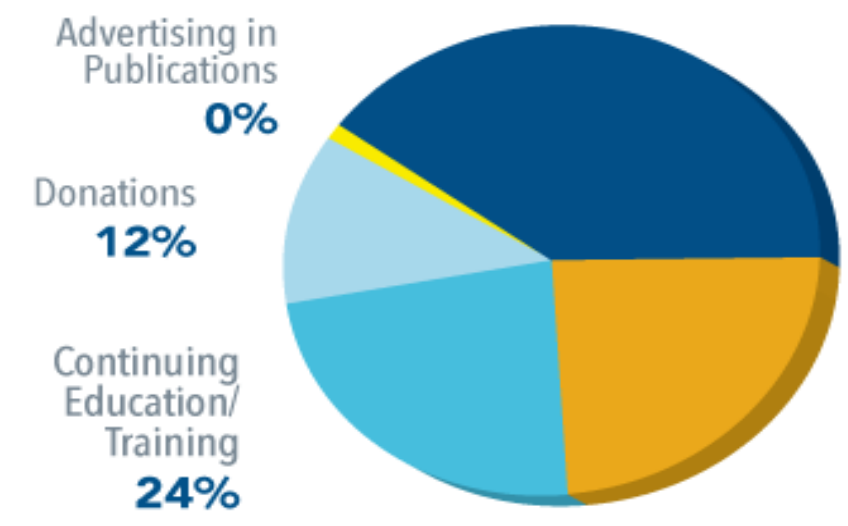

\author{
Conference \\ and Events \\ $41 \%$
}

Source: Naylor Association Solutions and Association Adviser, 2017

Grants. Grants are gifts to non-profit organizations to help further their mission. While it would be ideal to have a professional grant writer seek out grants and write proposals, this is often not realistic, especially for a start-up industry council. Often the grant search process is done by a volunteer who uses the Internet and his/her network to find grants for which to apply.

The first place to start searching for grant opportunities is with the members of the board. The companies which employ the board members often have a foundation that can be a source of financial support. There may be a family foundation in your community that has an interest in funding an industry council. Often decisions about which grants to fund are made by a board of trustees.

Other sources are local, state, or federal governments. These institutions will often issue a request for proposal (RFP), which is an announcement that there is grant money available. Regional Associations of Grantmakers (RAG) can provide a list of foundations in your region. RAGs are membership groups of organizations and individuals who practice philanthropy in specific areas.

Donations. Because councils are part of the university, individuals or companies donating to your council will be donating to the university which will direct funds to your council. Companies will often ask for a W-9 forms (tax identification number and certification) and proof of tax-exempt status when donating. Contact your campus financial officer for these forms and keep copies handy for future requests. It is vital to implement a process to track donations and follow-up actions (i.e., thank you notes, certificates of appreciation, etc.).

Sponsorships. Some events may have sponsors, or event planners may ask donors to make a monetary contribution in exchange for benefits (recognition, access to an event, food, etc.). Universities must consider the value of any benefits offered to sponsors or donors to comply with laws concerning what counts as a charitable gift. Some benefits provided to sponsors and donors have no impact on whether a gift is considered "charitable." These are called "permissible" benefits. "Impermissible" benefits do have an impact and should be avoided. For example, it is often permissible to use the sponsor's name and logo on event materials, but it may be impermissible to provide inducements for university members to purchase a 
sponsor's products. There are many rules regarding securing sponsorships, so it is advised to check with your development office before soliciting sponsorships.

\section{Stage 3 - Day-to-Day Operations}

After the preliminary formation activities, it is ideal for a director to run the council's day-to-day operations. This could be a faculty or staff champion, or a person hired for this purpose. The Council for Retail and Sales did not hire a part-time director until nine months after formation. It was determined that a part-time person was needed to maintain the website, help promote events, and manage membership and the budget. While it is tempting to hire an intern, it is strongly suggested that the director be a professional who has industry experience. Often this person is the face of the organization, and knowledge and experience will prove beneficial. In addition, a professional is more autonomous and does not require the supervision that an intern might. An intern may be utilized as an assistant to the director. An exception to this may be a graduate student with significant experience.

Board Meetings. Board meetings should be held regularly, at least three times a year. The Council for Retail and Sales holds board meetings one to two times a semester. The meetings are held on a weekday in the mornings, typically 8 a.m. -9 a.m. We leverage Zoom technology for those who cannot be present in person. For those attending in person, the time before and after the meetings are spent networking.

Event Planning. Events are a great way to increase interactions between students and professionals. They can also educate stakeholders on various issues that impact the industry. Your budget will dictate the types of events your organization hosts. Events can also be a way to raise money. For any event, it is important to plan well ahead of the event to ensure strong attendance. Planning should occur six months to a year before an event.

Collegiate Case Competitions. Case competitions fall under the experiential learning umbrella. These competitions benefit students, faculty members, the academic institution, and the sponsoring organization. For example, Benigni, Heng, and Cameron (2004) found that clients involved in experiential student exercises are very satisfied with the experience, and often this satisfaction translates into offering students internships or jobs based on the performance in the projects. Several academic accreditation organizations require an experiential learning component. For example, the Association to Advance Collegiate Schools of Business (AACSB) International requires active student involvement in the learning process as a part of their accreditation criteria (AACSB, 2018).

\section{Benefits.}

For Students.

- Allows students to look at a problem posed by a company through different perspectives

- Provides experiential learning

- Provides experience working in teams

- Students apply what they learn in class to a real-world scenario

- Students learn how an organization operates

- Networking opportunities with other students and professionals

- Potential to secure jobs/internships

- The educational and fun experience is often a highlight of a student's college experience.

- Develops conflict resolution skills

- Develops leadership skills

For Sponsoring Organizations.

- The sponsor can keep and implement any ideas proposed by students

- Helps sponsor to connect to potential future interns/employees (recruitment)

- Provides a connection to universities that send teams

- The competition is excellent for public relations/marketing

- Company participants are educating students/faculty on their products/services

- The cost of sponsoring can be deducted as a donation to a non-profit organization 
Networking Events. Networking events allow participants to meet new people. People at these events often exchange ideas and share information that may be valuable in one's career. These events increase the visibility of the organization as well as attendees. The Council for Retail and Sales often invites students to networking events to provide experience and access to professionals in the industry. These events also allow professionals to recruit students.

Speed networking events for students and professionals are popular. This is a fast-paced event designed to allow participants to interact with many people in a short amount of time, usually three to five minutes. Typically, a facilitator keeps the time and signals to participants when it is time to move to a new person. Speed networking lasts 45 minutes to an hour 1 hour, and, at the end, there is available time to continue to network on an informal basis. Students feel more comfortable with this networking format because they are not under as much pressure to initiate conversation and the structure of the event allows them to meet more people.

Full-Day Events. Full-day events tend to be workshops or symposiums centered around a theme of importance to the industry. While these events take a lot of time and effort to plan, they tend to increase visibility and establish the organization's expertise. Planning for full-day events often starts six months to a year out.

Coordination among several departments at the university is required. For example, when organizing an event, the Marketing Communications departments helps to develop public relations and marketing material for events.

Full-day events may also be a way to generate funds. It helps to develop a budget early in the planning process. This will determine how much to charge for the event based on the venue, food costs, speaker costs, etc. In our experience, the majority of our speakers are unpaid to minimize costs. If possible, we prefer to host the event at the sponsoring organization's facility. This avoids paying for a venue, provides additional exposure for the sponsor and a unique experience for the attendees.

Online Event Management Platform Approved by the University. One of the decisions to be made during event planning is how to collect information and money from participants. There are many popular online platforms available such as Eventbrite, EventZilla, and Brown Paper Tickets. Unfortunately, many times universities do not approve external even management platforms and may charge the council to use an internal system.

Building Membership. It is important for any organization to build membership. The first way to build membership is through word of mouth. The members of the board will be advocates who will bring in new members. It is essential to reach out to people employed in the industry and share the mission and vision of the industry council. If charging a membership fee, offer different payment methods and allow people to pay on a plan.

The CRS built membership through the following ways:

- Collecting names/emails at all our events

- Tapping our local student business club and offered free membership to members.

- Creating an online membership form

- Using the lure of free membership on our promotional material

- Reminding current members to bring in new members to events

We may decide to start charging for membership in the future but currently do not charge as we want to continue to build critical mass. Even if we decide to charge for membership, we do not anticipate charging students to join.

\section{Student Involvement.}

Participation. Students can benefit from an industry council in many ways, as noted above. Participation in networking events often leads to relationships with professionals. These relationships may take the form of a formal or informal mentor arrangement. Students may also help in coordinating events. To increase student involvement, for paid events, students often received a reduced or free admission.

Internships. Professional members of an industry council are often looking for student interns or graduates for full-time positions. The creation of an internship committee may be of value. It is important 
to work with career services to ensure internships are appropriately recorded and managed. The benefits of internships for students include:

- Learning from experienced professionals

- Providing financial reward

- Encouraging career exploration

- Amassing experience for their resume

- Networking

- Learning about how to navigate workplace issues

- Opening the possibility for a permanent position

The employers also benefits by increasing visibility on college campuses, testing out potential employees, getting different perspectives on projects, giving back to the community through mentoring interns, and the advantage of lower-cost labor.

\section{SUMMARY}

The Council for Retail and Sales has been an excellent way to grow department and university presence. The idea of innovation, entrepreneurship, and intrapreneurship applies to all industries. Industry councils bring together professionals, faculty and students, and ideas for programming regularly come from members. Members are involved with the campus community and students. Excitement is generated through events, education, and participation. According to a Vice President of a large insurance company who is involved with our council, "I continue to be astounded with what is developed by the efforts of all those involved. From the student challenges to the ideas generated for our partners, to the impacts on our communities, it is nothing short of extraordinary." Another board member stated, "The Council creates a tremendous amount of value for our organization. Our partnership has provided us a unique opportunity to discuss and collaborate on challenges that face the supply chain in the chemical and ingredient industry. Networking with industry professionals, students, faculty, and local leadership allows our company to work together and find new solutions to some of the commercial challenges we face." It is time to consider branching out your campus's efforts with the formation of an industry council!

\section{REFERENCES}

AACSB. (2018). 2013 Eligibility Procedures and Accreditation Standards for Business Accreditation (revised 2018). Retrieved from https://www.aacsb.edu//media/aacsb/docs/accreditation/business/standards-and-tables/2018-businessstandards.ashx?la=en\&hash=B9AF18F3FA0DF19B352B605CBCE17959E32445D9

Benigni, V., Cheng, I., \& Cameron, G.T. (2004). The Role of Clients in the Public Relations Campaigns Course. Journalism \& Mass Communication Educator, 59(3), 259-277.

Community Tool Box. (2019). Chapter 9, Section 7: Writing Bylaws. Center for Community Health and Development at the University of Kansas. Retrieved from https://ctb.ku.edu/en/table-ofcontents/structure/organizational-structure/write-bylaws/main

Developing a Mission Statement: A Step-by-Step Exercise for Creating a Mission Statement. (n.d.). Retrieved from https://nonprofithub.org/wp-content/themes/nonprofithub/img/landingpages/mission/nonprofithub-missionstatement.pdf

Fernley \& Fernley Inc. (2018). How to start an association. Retrieved from http://www.fernley.com/resources/start_an_association.asp

Hall, M.C. (2017). NCR Silver. Retrieved from https:/www.ncrsilver.com/how-to-start-a-tradeassociation-for-your-industry/

Ibele, T. (2017). How to start an association step by step. Wild Apricot. Retrieved from https://www.wildapricot.com/blogs/newsblog/2017/11/24/how-to-start-an-association\#what

Lamont, L.M., \& Friedman, K. (1997). Meeting the Challenges to Undergraduate Marketing Education. Journal of Marketing Education, 19, 17-30. 